TWENTY-THREE

\title{
Diversification of the Amazonian flora and its relation to key geological and environmental events: a molecular perspective
}

\author{
R. Toby Pennington ${ }^{1}$ and Christopher W. Dick ${ }^{2}$ \\ ${ }^{1}$ Royal Botanic Garden Edinburgh, UK \\ ${ }^{2}$ University of Michigan, Ann Arbor, Michigan, USA
}

\begin{abstract}
This chapter provides a molecular perspective on Neogene plant diversification in the Amazon drainage basin. The history of Amazon plant diversification must be understood in a broader context of migration of lineages from other continents during the Neogene and earlier periods. The history of major migration events, as revealed by recent molecular systematics research, is reviewed here. These studies demonstrate the role of land bridge migration and oceanic dispersal in forming contemporary Amazon plant diversity. Many of the diversification histories coincide geographically and in timing with the uplift period of the Andean orogeny and, in some cases, with Pleistocene climatic changes. Although the Pleistocene history of Amazon vegetation is poorly understood, population genetics approaches may help to elucidate the occurrence of population contractions and expansions and their relation to putative moist forest refuges during glacial periods. The overlay of ecological traits, such as soil or habitat preference, onto phylogenies highlights the role of habitat specialization in plant diversification across the Amazon drainage basin. This review suggests that collaboration between molecular systematists, ecologists, geologists and palaeobotanists will advance future research on the driving factors of Amazon plant diversification.
\end{abstract}

\section{Introduction}

In this chapter we discuss biogeographical hypotheses relevant to Neogene Amazon history. These include (i) the role of Gondwana vicariance and oceanic dispersal in shaping the Paleogene flora; (ii) the role of the Isthmus of Panama and Great American Biotic Interchange on Amazonian plant diversity; (iii) the role of the Andean uplift as a source of plant diversity and as a geographic barrier for lowland plant species; (iv) the role of Pleistocene climate change as a driver of speciation; (v) the role of edaphic heterogeneity in adaptive divergence; and (vi) the role of speciation between biomes. In reviewing research relevant to understanding the contribution of these diverse processes, our approach emphasizes advances from molecular systematics and, to a smaller degree,

Amazonia, Landscape and Species Evolution: A Look into the Past, 1st edition. Edited by C. Hoorn and F.P. Wesselingh.

(C) 2010 Blackwell Publishing population genetics, which have generated a substantial change in our perspective of diversification histories.

\section{Overview of molecular methods}

In conjunction with fossils and geographical data, molecular techniques hold great promise for inferring the biogeographical histories of populations, clades and communities and, ultimately, for addressing the question of why there are so many species of plants in the Amazon drainage basin.

This review will draw largely upon inferences from phylogenies, at or above the species level, derived from DNA sequences. This field of molecular phylogenetics can be contrasted with that of molecular population genetics, which examines genetic variation of populations. Bridging these two approaches is phylogeography, which uses molecular data to examine the geographical history of closely related species or geographical lineages. Population genetic and phylogeographic studies are poorly developed for 
Amazonian plants. Recent biogeographical inference in molecular phylogenetics has frequently used techniques that permit the inference of absolute time from a phylogenetic tree derived from DNA data, but such methods have limitations, which are important to consider.

The two commonly used approaches to inferring divergence times using DNA sequences are (i) fossil-calibrated DNA phylogenies, and (ii) 'borrowed molecular clocks', which use a range of substitution rates inferred for other taxa. Both approaches can take account of the fact that nucleotide substitution rates are seldom, if ever, homogeneous or clock-like (Li 1997).

In the first approach a date is assigned to a given bifurcation (node) in a phylogeny using fossil evidence that can provide a minimum age for the common ancestor of a group. Several algorithms are available that can allow for variation in substitution rate and date all nodes in a phylogeny using one or more fossil calibrations (reviewed by Renner 2005; Rutschman 2006). Fossil calibrations produce misleading results if the fossil records are not accurately dated or if they are assigned to the wrong phylogenetic node (Graur \& Martin 2004). Assignment of fossils to nodes on phylogenetic trees requires detailed knowledge of the morphological features of the extant taxa, and where these features have changed in the phylogeny (see Renner 2005), and this information is often lacking. Multiple fossils (e.g. Lavin et al. 2005) are desirable because they provide independent calibrations that can be cross-validated (Near \& Sanderson 2004). However, the paucity of Late Cretaceous and Tertiary macrofossils from South America and Africa means that multiple fossil calibrations will seldom be possible for tropical taxa, and that the age of some large tropical tree clades may be underestimated simply because their fossils have not been discovered (Heads 2005). Fossil pollen is more widespread than macrofossils and has been used to infer the age and geographical origin of rainforest tree species (Dick et al. $2003,2007)$. The utility of fossil pollen, however, varies greatly among plant groups because its morphology can be uniform even among some large families. Dates can also be assigned to nodes using geological events, such as the timing of separation of continental land masses or the emergence of oceanic islands (e.g. Plana et al. 2004). However, such geological calibrations are less preferable than fossils because of the possibility of more recent dispersal, which has been repeatedly inferred from fossilcalibrated phylogenies (e.g. Lavin et al. 2004).

'Borrowed molecular clocks' using substitution rates calculated from other taxa have been applied in the absence of fossils, but are no more reliable than the rate estimates made in the original studies. This method assumes that DNA of the study taxon evolves at a rate somewhere between the fastest and slowest published rates of nucleotide substitution for a given genetic region (Richardson et al. 2001; Dick et al. 2003; Kay et al. 2006). Published rates of nucleotide substitution for single regions can vary by orders of magnitude, but the range of rates applied to a particular taxon can be narrowed by consideration of life history because generation time is inversely correlated with substitution rate (e.g. Gaut 1998; Kay et al. 2006), meaning that herbaceous lineages have accumulated substitutions at a more rapid rate than most trees. Therefore if the taxon of interest is a herb, it is reasonable to apply substitution rates calculated from other herbaceous taxa rather than from trees, the rates of which may be too slow.
Even when multiple fossil calibrations are available, confidence intervals on dates for individual nodes are seldom narrower than one million years, and often as much as five million years, meaning that it is hard to pinpoint dates with even million-year accuracy. Dating with precision using the 'borrowed molecular clocks' technique is even more difficult because substitution rates calculated from other taxa can vary by an order of magnitude, and this variability must be accounted for. However, despite their approximate nature, molecular clock methods have been powerful in choosing between biogeographical scenarios that are well separated in time. For example, using fossil calibration, Särkinen et al. (2007) evaluated three biogeographical hypotheses of Gondwana vicariance, boreotropical dispersal and recent trans-Atlantic dispersal as explanations for the amphi-Atlantic distribution of Renealmia (Zingiberaceae). Because they are separated by at least 35 million years, the same three biogeographical hypotheses were evaluated as explanations of the amphi-Atlantic disjunction of the kapok tree, Ceiba pentandra, using substitution rates from other taxa (Dick et al. 2007). However, in the context of this volume, molecular clock techniques, even phylogenies calibrated by multiple fossils, are too approximate for distinguishing between more closely timed or overlapping events. These include many important geological events of the Neogene associated with Amazonia such as the Andean orogeny and marine incursions into the Amazon drainage basin.

Resolution of Neogene speciation events is further constrained by generally slow rates of nucleotide substitution in plants compared with the relatively fast evolving mitochondrial DNA (mtDNA) of animals. The primary source of molecular markers for comparative studies in plants, chloroplast DNA (cpDNA), evolves 10 times more slowly than animal mtDNA (Wolfe et al. 1987). The Internal Transcribed Spacer (ITS) may be the only nuclear region that can be easily sequenced across diverse plant lineages using universal primers and without the cloning that is necessary to separate the multiple copies of most nuclear loci. The ITS region has been used for intraspecific analyses of divergences in the Neogene and older (e.g. Dick et al. 2003). However, the ITS region does not show sufficient variation among species in some important clades of relatively recent origin (e.g. PliocenePleistocene), such as the rainforest tree genus Inga (Richardson et al. 2001); and the slow rate of substitution in some woody plant lineages may preclude analysis of Pleistocene divergence times. Thus the most reliable inferences of divergence times for Amazonian plants are for relatively old clades.

\section{Gondwana and boreotropical origins of the Amazonian flora}

Are tropical rainforests cradles of recent speciation, and hence composed of relatively young species, or are they museums of equable climate in which lineages have accumulated over long periods of time? This question has shaped discussion of Amazonian species diversity since the Victorian era (Wallace 1878; Stebbins 1974). It is now clear that South American rainforests were species rich in the early Tertiary (Jaramillo et al. 2006), and that some plant lineages in present-day Amazonian forests are ancient (e.g. some palms; Dransfield et al. 2008). Conversely, species origins 
as recent as the Pleistocene have been demonstrated in other plant genera (e.g. Inga; Richardson et al. 2001; Lavin 2006). However the dichotomy provided by the museum and cradle metaphor is a starting point for thinking about the age and diversification histories of tropical plant lineages (Richardson et al. 2001). The older history, leading back to the origin of angiosperms (Morley 2000), is the stage on which more recent rainforest plant histories are overlain. The Paleogene history is also a necessary background for evaluating intercontinental dispersal during the Neogene.

In accord with the seminal paper of Raven \& Axelrod (1974), Gentry (1982) considered the Amazonian flora to be a relict of the Mesozoic Gondwana flora. This was a parsimonious explanation for the range disjunctions of many families and genera shared between South America and Africa (Thorne 1973). In addition to the taxonomic similarities, Gentry (1993) found that many of the same families and genera dominated rainforest inventory plots on both continents. Because South America separated from Africa approximately 96 million years before present (Pitman et al. 1993), the Gondwana hypothesis implied that rainforest tree communities in Africa and the Neotropics have not changed dramatically since the age of dinosaurs. The Central American flora, on the other hand, was thought to represent lineages of Laurasian origin until land connection with South America (the closure of the Panama Isthmus) permitted invasion of Gondwana-derived lineages (Gentry 1982). In some cases, such as the calamoid palms, molecular phylogenies have corroborated the Gondwana vicariance scenario or dispersal across a narrow proto-Atlantic soon after Africa and South America separated (e.g. Dransfield et al. 2008). One of the most characteristic Amazonian palms, Mauritia, and its relatives Mauritiella and Lepidocaryum, are estimated to have split from their African sister group, Raphia, in the Late Cretaceous (W. Baker et al. unpublished), which agrees with the Late Cretaceous/Early Tertiary fossil pollen record attributable to this group in both South America and Africa (Baker \& Dransfield 2000).

Raven \& Axelrod's (1974) plate tectonic model has since been revised to include boreotropical plant migrations. The boreotropical hypothesis references a warm phase in the Earth's climatic history during which frost-intolerant (megathermal) vegetation extended much further north than it does today (c. 45 to $50^{\circ} \mathrm{N}$ latitude). A North Atlantic land bridge near what is now Greenland permitted overland dispersal of northern megathermal (boreotropical) plant species between Europe and eastern North America during the Eocene (54-35 Ma) (Tiffney 1985; Morley 2000). Because some of the boreotropical flora was derived originally from Africa, the North Atlantic land bridge provided a circuitous dispersal path permitting exchange between Africa and North America. From North America, it is hypothesized that some lineages subsequently reached the Amazon drainage basin (Morley 2003). Fossil-calibrated phylogenies suggest that some lineages of the Burseraceae (Weeks et al. 2005), Meliaceae (Muellner et al. 2006), Annonaceae (Richardson et al. 2004), Moraceae (Zerega et al. 2005), Lauraceae (Chanderbali et al. 2001), Sapotaceae (Smedmark \& Anderberg 2007) and Melastomataceae (Renner et al. 2001) arrived in South America via the boreotropical route; whereas Malpighiaceae (Davis et al. 2002) probably spread from South America to Africa and Asia through this route.
The boreotropical dispersal model is supported by revised age estimates of some pantropical families that postdate the break-up of the Gondwana land mass by many millions of years and which are represented in fossil records of Europe and North America. For example, the legume family is the dominant tree family in rainforests in Africa and South America, but fossil records and molecular clock analyses suggest that the entire family is younger than 65 million years (Lavin et al. 2005).

\section{Panama Isthmus}

The classic zoogeographical view of South American biogeography (e.g. Simpson 1980; Gentry 1982) invoked a special role for the closure of the Panama Isthmus. The closure of the Isthmus (c. $3 \mathrm{Ma}$ ), allowing overland migration, ended the isolation of South America, which had started with its split from Africa (c. $96 \mathrm{Ma}$ ). The migration of animals was viewed as so substantial that it is often termed the 'Great American Interchange' (Simpson 1980; Stehli \& Webb 1985). Gentry (1982) suggested that any floristic exchange had been asymmetric, because he inferred the presence of more 'Gondwanan' elements in Central America than 'Laurasian' elements in South America. He posited that Central American flora largely comprised widespread or 'weedy' species of Amazonian origin. Yet Gentry considered the Laurasian immigrant flora to Amazonia as negligible, with most Laurasian elements in South America being confined to the high Andes.

However, molecular phylogenies have shown many of Gentry's examples of Gondwanan groups to be later arrivals in South America (Pennington \& Dick 2004; see above), which necessitates a re-evaluation of both the importance of the Panama Isthmus as a migration route (because many plants are better marine dispersers than Gentry assumed) and of any asymmetry of migration that did occur once the Isthmus closed.

Several phylogenies of plant taxa from both South and Central America show geographical structure around the Panama Isthmus (Fig. 23.1), for example with a monophyletic Central American clade nested within a paraphyletic South American group (indicating migration from south to north; e.g. Chaetocalyx/Nissolia Pennington et al. 2004a), or vice versa, with a monophyletic South American clade nested within a paraphyletic Central American group (indicating migration from north to south; e.g. GuatteriaErkens et al. 2007). Such phylogenetic patterns might have been interpreted (e.g. Gentry 1982) as evidence of migration across the Isthmus once it closed, which would predict dates for an 'Isthmian stem node' (see Fig. 23.1) of 3 Ma or less (Coates \& Obando 1996). However, dated phylogenies indicate that this view is too simplistic because dates of Isthmian stem nodes often predate $3 \mathrm{Ma}$, sometimes by tens of millions of years. These older dates of arrival in South America have ignited interest in geologically earlier overland or island-hopping routes from North American to South America, such as the proto-Greater Antilles and the Great Antilles and Aves Ridge (Iturraldi-Vinent \& MacPhee 1999), but the prevalence of transoceanic dispersal explanations for intercontinental disjunctions (see below) implies that overwater dispersal is likely also to have played a role.

The early trans-Isthmian divergence times ( $>3 \mathrm{Ma}$ ) probably reflect the ability of many plants to disperse over small water 


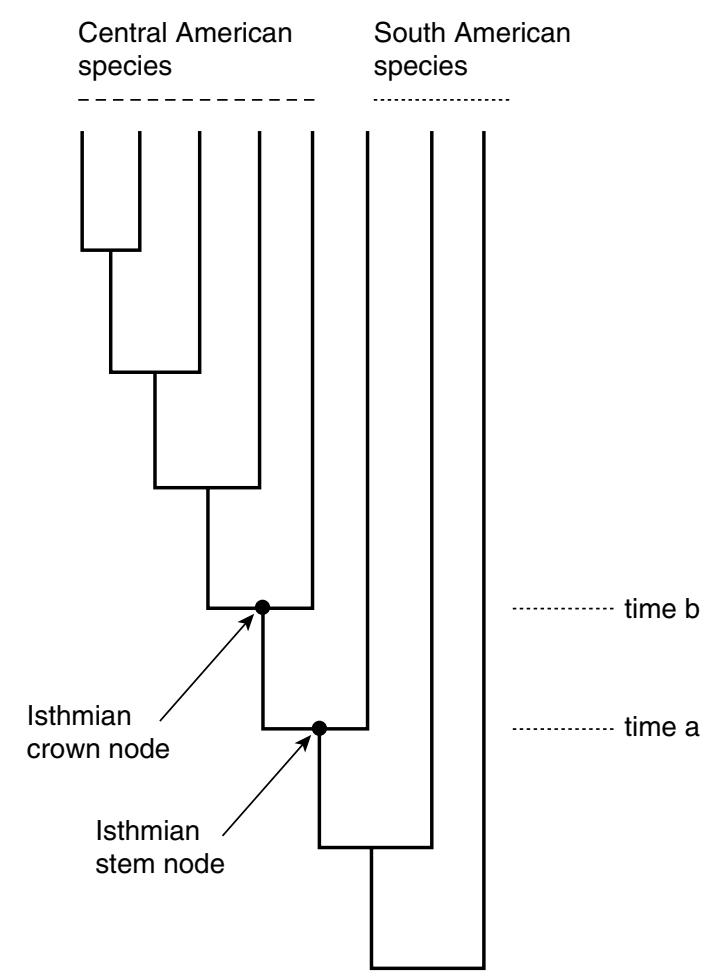

Fig. 23.1 Hypothetical phylogeny of plant species endemic to South and Central America showing geographical structure around the Panama Isthmus. Branch lengths are proportional to time. The Central American clade nested within a South American group indicates migration from south to north (the reverse pattern would indicate migration from north to south). There is evidence of migration across the Isthmus once it closed if the date of the 'Isthmian stem node' (time a) is dated as $3 \mathrm{Ma}$ or less. Note that the movement from South to Central America could have occurred at any time between the Isthmian stem and 'crown' nodes (times $a$ and b), and therefore the date of the stem node is the earliest possible time of south-north movement.

barriers. Examples of earlier movements are in the Burseraceae (Weeks et al. 2005; three migrations to South America dated c. 24-52 Ma), genera in the 'short branch clade' of Annonaceae (Pirie et al. 2006; arrival in South America c. 51-16 Ma) and the Ocotea complex of Lauraceae (Chanderbali et al. 2001; arrival in South America c. 20-23 Ma). Some of these taxa, such as Protium (Burseraceae), the Ocotea complex (Lauraceae) and Guatteria, are significant in Amazonian rainforests both in terms of abundance and species richness (Pennington \& Dick 2004). More recent pre-Isthmian immigrants include Ruprechtia (Pennington et al. 2004a), which migrated from South to Central America c. $4 \mathrm{Ma}$, and Guatteria (Erkens et al. 2007), which must have arrived in South America from Central America between c. 6 and 8 Ma, although the lack of resolution in the Guatteria phylogenetic tree makes exact identification of the Isthmian crown node problematic.

Gentry's (1982) assertion that Central American rainforests are dominated by widespread Amazonian taxa remains to be tested. Indeed, as Gentry pointed out, many tree species are distributed in both Central and South America. In the forests of the Panama Canal watershed, for example, at least $433(61 \%)$ of the 714 known tree species have conspecific populations in South America east of the Andean cordilleras (Dick et al. 2005). It should be possible to test the geographical origin of these widespread species using a phylogeographical approach with multiple accessions of widespread species, and in the context of a genus-wide phylogeny. However, that all these widespread distributions across the Panamanian Isthmus were achieved by overland migration across the Isthmus seems unlikely, and we predict that pre-Isthmian, over-water dispersal will have to be invoked in many cases, as has been demonstrated for the rainforest tree Symphonia globulifera (Dick et al. 2003).

\section{Evidence for transoceanic dispersal}

Sweepstakes dispersal can be inferred from DNA sequence phylogeography and molecular clock methods (Renner 2005). If the genetic divergence between disjunct populations is much less than expected under the timescale implied by a vicariance or overland migration hypothesis, then long-distance dispersal is inferred as the cause of the population disjunction. This approach was used to infer oceanic dispersal from Africa to the Neotropics of Symphonia globulifera (Dick et al. 2003). The fossil-based analysis indicated that three separate oceanic dispersal events led to the establishment of S. globulifera populations in Central America, South America and the West Indies during the Neogene. A similar genetic analysis of the kapok tree, Ceiba pentandra (Malvaceae), demonstrated that African populations established through oceanic dispersal from a Neotropical source at least 13,000 years BP (Dick et al. 2007). Neither Symphonia globulifera nor Ceiba pentandra is specifically adapted to marine dispersal. In species adapted for water dispersal, such as mangroves (Nettel \& Dodd 2007), trans-Atlantic dispersal may occur frequently and at ecological as well as geological timescales.

At higher taxonomic levels, dated phylogenies are repeatedly rejecting plate tectonic explanations for intercontinental distributions (see above), and are consistent with long-distance transoceanic dispersal explanations. The case of the legume family is particularly instructive with respect to Amazonia, because legumes dominate large areas of the Amazon rainforest. A dated molecular phylogeny for the Leguminosae (Lavin et al. 2004; 2005) that focused on 44 transoceanic sister clades showed that the majority of the amphi-Atlantic disjunctions date to only c. 6-16 Ma, implying that sweepstakes dispersal during the Neogene has played a major role in shaping the intercontinental taxonomic affinities of the legume family. It seems likely that this scenario for legumes also applies to other families, and may explain many of the floristic similarities in the equatorial forests of Africa and the Neotropics (Gentry 1993; Thorne 1973).

Community assembly of Amazonian forest trees: Yasuní forest

It is instructive to assess the impact of cross-Isthmian and oceanic dispersal at the community level for Amazonian forest trees. Pennington \& Dick (2004) evaluated the role of intercontinental 
immigration in structuring the taxonomic composition of trees in a 25-hectare forest inventory plot in the western Amazonia at Yasuní, Ecuador (Valencia et al. 2004). 'Immigrants' were defined as species belonging to lineages that originated outside of South America after its separation from Africa. The immigrant group included the Leguminosae (Lavin et al. 2005; Schrire et al. 2005), Annonaceae (Richardson et al. 2004), some Lauraceae (Chanderbali et al. 2001) and Melastomataceae s. str. (Renner et al. 2001). Of the 1104 tree species identified in the Yasuní forest, 232 (21\%) belonged to families and genera classified as immigrants. Some of the immigrant lineages may have arrived directly from Africa via marine dispersal, as in the case of Symphonia globulifera, while others may have crossed the Panama land bridge. Summed over geological time, intercontinental migration and long-distance dispersal events contributed substantially to the taxonomic composition of a speciesrich Amazonian tree community. The number of 'immigrants' in this study was probably underestimated because it did not include subsequent studies that demonstrate recent, non-South American origins of families important in Amazonia such as Meliaceae (Muellner et al. 2006) and Burseraceae (Weeks et al. 2005).

\section{Andean orogeny}

At the time of the closure of the Isthmus of Panama in the Pliocene, the northern cordilleras of the Andes were rising to their present elevations. The Isthmus of Panama acted as a bridge for terrestrial plants and a barrier for marine organisms. Similarly, the uplift of the northern Andean cordilleras provided a bridge for coldtolerant North American plants such as oaks and alders, while acting as a barrier to the interchange of lowland rainforest plants.

Reviews of the timing of the orogeny of the tropical Andes are provided by Mora et al. (see Chapter 4), Gregory-Wodzicki (2000) and Antonelli et al. (2009). It is clear that much of the uplift is very recent, with the mountains only having approximately half of their current elevation $10 \mathrm{Ma}$. For example, 6-7 Ma fossil deposits from Bolivia, now at $3600 \mathrm{~m}$ elevation, contain a mixture of cloud forest and mid-elevation taxa, indicative of an ecotone between these vegetations, which is currently located at c. 1200-1400 m elevation (Graham et al. 2001). These fossils are therefore indicative of substantial recent orogeny, even if warmer Neogene climates meant that the ecotone was then at slightly higher elevation. Collectively all data indicate that high-elevation habitats in the tropical Andes such as cloud forest and paramo originated recently, from the Pliocene onwards (Van der Hammen et al. 1973).

\section{Speciation of Andean dry forest and high-elevation taxa}

It is possible that old lineages from temperate southern South America migrated to the geologically recent high-elevation habitats in the tropical Andes. However, dated molecular phylogenies suggest that some of the high-Andean plant diversity arrived relatively recently by long-distance dispersal from mid-latitudes (e.g. temperate northern hemisphere for Lupinus and Lathyrus - Kenicer et al. 2005; Hughes \& Eastwood 2006). Moreover, a large part of the present species diversity originated in the past few million years in sometimes spectacular radiations, for example Jamesonia, Eriosorus (Sánchez-Baracaldo 2004); Lupinus (Leguminosae - Hughes \&
Eastwood 2006); Draba (Brassicaceae - Koch \& Al-Shehbaz 2002); Fuchsia (Onagraceae - Berry et al. 2004). The rising tropical Andes have therefore been a 'cradle' of recent speciation in high-elevation habitats. In low-elevation seasonally dry forests confined to interAndean valleys in Ecuador, Peru and Bolivia, the ages of lineage diversification in clades of Ruprecthia (Polygonaceae), Coursetia and Poissonia (Leguminosae) are consistent with a scenario of speciation driven by the Andean orogeny, probably caused by vicariance of a historically wider expanse of dry forest (Pennington et al. 2004a, 2006a).

For birds, Fjeldså (1994) has suggested that montane regions can act as a 'species-pump', and that adjacent lowland forest receives these highland species, adding to its diversity. This may have occurred in Africa (Fjeldså \& Lovett 1997), but it is less clear whether it is the case for Neotropical birds. Brumfield \& Edwards (2007) show only a few examples of highland species of Thamnophilius antshrikes giving rise to species restricted to the lowlands, although the case of highland species giving rise to daughter species that occupy both highland and lowland habitats is more frequent. We are not aware of any examples of 'downhill' speciation into Amazonia for plants, but this may reflect the lack of studies that have searched for it. Phylogenetic studies of clades that contain both lowland, mid-elevation and cloud forest species (e.g. Lauraceae) would be instructive in this regard.

Radiation of lowland and mid-elevation 'Andean-centred' taxa

An increasingly prevalent paradigm (e.g. Fjeldså 1994; Young et al. 2002) to explain why diversity is so high in the Neotropics (and Amazonia in particular) is Gentry's (1982) model of explosive Andean diversification at mid-elevations. Gentry (1982) hypothesized that explosive evolution in 'Andean-centred taxa', concomitant with the Andean orogeny, may have given rise to almost half of all Neotropical species. Such explosive evolution has now been clearly demonstrated for some high-elevation taxa such as Lupinus (see above). However, the high alpha-diversity (species diversity found in a small, uniform area) in South America that Gentry sought to explain is found in the Amazonian lowlands and lower to middle elevation forests on the Andean flanks rather than in the higher elevation temperate and alpine habitats. Gentry suggested recent speciation in northern-Andean-centred genera of epiphytes, understorey shrubs and palmettos that are characteristic of middle elevation forests and often pollinated by hummingbirds, nectar-feeding bats and euglossine bees.

Several time-calibrated phylogenies support Gentry's hypothesis (e.g. Kay et al. 2005; Särkinen et al. 2007). For example, one of Gentry's central examples was the ginger Renealmia (Gentry 1982, p. 574, fig. 2), which has been shown to have diversified in the past c. 15.8-2.7 Ma (Särkinen et al. 2007). Phylogenies of the Andeancentred Costus (Costaceae), Inga (Leguminosae), Cremastosperma, Klarobelia, Malmea, Mosannona (Annonaceae) and vegetable ivory palms (tribe Phytelephae, Palmae) provide some support in showing diversification over the past c. 25 million years, concomitant with the rise of the tropical Andes (Richardson et al. 2001; Kay et al. 2005; Pirie et al. 2006; Trénel et al. 2007). Apart from Costus and Renealmia, these are trees, although Inga, in its 
species richness (300 spp.; Pennington 1997), short generation time (Richardson et al. 2001), pollinators that include hummingbirds, and its distribution centre in the low- and mid-elevation forests of the northern Andes, has all the other characteristics that Gentry ascribed to Andean-centred genera that he considered to have diversified explosively.

It will be well worth examining the timing of diversification of other Andean-centred groups, such as the species-rich Macrostachys clade of Piper (c. 100 species centred in the northern Andes and Central America; A. Jaramillo et al. 2008). However, a problem with testing the Andean orogeny hypothesis is that the major uplift of the tropical Andes over the past 25 million years overlaps in time with other events hypothesized to have had radical effects on Neotropical biota such as the Amazon megawetland (23-10 Ma), the closure of the Panama Isthmus (c. $3 \mathrm{Ma}$ ) and Pleistocene glaciations (last 2 million years). Hence, it is hard to disentangle the relative effects of these events on diversification from dated phylogenies alone because of the overlap of dates and the broad confidence intervals for even the most accurately dated phylogenies. Hence the recent speciation of Inga (all extant species arising in the last 6 million years; Richardson et al. 2001; Lavin 2006; M. Lavin et al. unpublished) coincides with the potential effects of at least three Neogene events: the Andean uplift, the closure of the Panama Isthmus and Pleistocene climate changes.

Gentry considered Pleistocene climatic changes to have been an important force in speciation for plant groups with a distributional centre in the Amazon drainage basin (which he termed 'Amazonian-centered'), but was clear in his inference that the dominant force for Neotropical speciation - the excess speciation that had resulted in the Neotropics being more species rich than any palaeotropical area - had been the Andean orogeny. Gentry brought other evidence to bear on his Andean speciation hypothesis, citing the high species numbers in Andean-centred genera (accounted for by 'explosive speciation'), the local endemism of these species (implying they arose where they are found, in the Andean foothills), and evidence for adaptive radiation and coevolution with pollinators, especially hummingbirds. Such additional evidence might be sought for Andean-centred examples such as Inga that Gentry did not discuss. For example the size of Inga species distributions might be investigated to see if species found along the flanks of the Andean mountains tend to show more restricted ranges than those found in Amazonia.

\section{Rainforest vicariance}

As well as driving active recent speciation, the early Andean orogeny must have disrupted the distribution of some lowland plant species. The northern Andean cordilleras presently form a virtually impassable migration barrier for lowland rainforest plant species, yet many such species exhibit range disjunctions around the Andes. In the lowland forests of Ecuador, for example, approximately $30 \%$ of the vascular plant species range east and west of the Andean cordilleras ( $n=1431$ disjunct species; Jørgensen \& León-Yánez 1999).

Cross-Andean genetic data are available for only a few widespread lowland tree species (Aide \& Rivera 1998; Dick et al. 2003, 2007). Of these, only the wind- and water-dispersed Ceiba pentandra showed low levels of divergence consistent with crossAndean dispersal (Dick et al. 2007). If up to one-third of the flora of northwest South America evolved prior to the rise of the northern Andes, as suggested by some authors (e.g. Raven 1999), then conspecific populations of more than 1400 lowland plant species may have diverged in genetic isolation for several million years, in a biome renowned for intense biotic challenges.

Above the species level, the genera Cremastoperma, Klarobelia, Malmea, Mosannona (Annonaceae; Pirie et al. 2006) and the vegetable ivory palms (tribe Phytelephae, Palmae; Trénel et al. 2007) all implicate the rising northern Andes as a barrier that has led to allopatric divergence and speciation. The tribe Phytelephae (three genera and eight species) occurs in the amphi-Andean lowlands of northwest South America and adjacent Panama. Only one species (Ammandra decasperma) occurs on both sides of the Andes, and the remainder are restricted to one of three areas separated by Andean cordilleras: western Amazonia, the Cauca and Magdalena valleys, and the Pacific Chocó. The separation of distinct species by the Andes (see also Chapters 17 \& 25) suggests allopatric divergence (Whitmore 1998), which is corroborated by a dated phylogeny whose branching order and timing corresponds 'surprisingly well to the sequential uplift of the cordillera of the northern Andes' (Trénel et al. 2007, p. 284). Cremastoperma, Klarobelia, Malmea and Mosannona are Andeancentred understorey trees found in lowland and premontane forests. In all four genera, no species is found on both sides of the Andes, and in Mosannona most species fall into two clades, one from the east and one from the west of the mountains (Pirie et al. 2006). Again, this distribution is suggestive of Andean vicariance driving divergence, a hypothesis supported by divergence dates from dated phylogenies (penalized likelihood estimates of 7-10 Ma for the onset of divergence of extant species in each genus, all of which are monophyletic). Amplified fragment length polymorphism (AFLP) and chloroplast DNA sequence data are also strongly suggestive that the northern Andes have been a major biogeographical barrier in Dussia (Leguminosae; Pennington et al. 2003 and unpublished).

Population-level studies of multiple species are needed to test the relative roles of dispersal and vicariance as the cause of crossAndean plant disjunctions. These studies will need to sample large numbers of species and take into account the major sources of error in molecular clock estimates over the Pliocene-Pleistocene time period. This error includes variation in nucleotide substitution rates across species, different effective population sizes, and different timing of population divergences. Such analytical methods are presently available or under development (Hickerson et al. 2006) but have not yet been used to test shared biogeographical histories in plants.

\section{Pleistocene climate changes}

The effects of Pleistocene refugia on population genetic structure of tree species have been investigated extensively in Europe. These studies have generally confirmed the inference of the location of Pleistocene forest refugia based on fossil pollen (Petit et al. 1997). The genetic signature of forest refuges consists of high genetic diversity of populations in the location of Pleistocene refuges 
and lower diversity in regions of Holocene reforestation (Hewitt 1996). However, areas of contact between expanding refugial populations ('suture zones') may have higher genetic diversity due to admixture (Petit et al. 2003). Furthermore, populations may be reduced to densities too low to register pollen, but high enough to maintain genetic diversity in 'cryptic refuges' (Petit et al. 2008). In a North American study, for example, McLachlan et al. (2005) found distinctive cpDNA haplotypes of red maple (Acer rubrum) and American beech (Fagus grandifolia) in northern regions thought to be devoid of these species during the Last Glacial Maximum. The interpretation of genetic signatures of Pleistocene forest history of the Amazon drainage basin may run into similar problems if some rainforest species experienced only reduced abundance or constriction to riparian areas rather than extinction in drought-prone areas.

In a genetic investigation of the caesalpinioid rainforest tree Vouacapoua americana in French Guiana, Dutech et al. (2003) found a single cpDNA haplotype spanning thousands of hectares in an area that became desiccated during the Last Glacial Maximum (LGM), and a diversity of haplotypes in regions that were probably forested during the LGM. This French Guiana study was performed at an ecotone between coastal rainforest and savanna, so it is perhaps unsurprising that it confirmed the suggestion that forest has spread at the expense of savanna in the currently wet interglacial (Granville 1982). Rapid, recent range expansion of Vouacapoua americana into the area that was dry during the LGM would produce the low observed haplotype diversity. A recent study of the effects of Pleistocene forest fragmentation on genetic diversity was performed on a lowland rainforest tree (Aucoumea klaineana; Burseraceae) in Gabon, Africa (Borne 2007). The authors found high levels of genetic diversity on the tops of small mountains and low levels of genetic variation in the intervening lowlands. The distribution of genetic diversity is consistent with fossil pollen studies that show higher elevation forests were moist and forested during the LGM, while the intervening lowlands were converted to parkland or savanna vegetation. Similar patterns may be expected in Neotropical regions with pronounced topographic relief, as in Central America.

These two tropical tree studies suggest that patterns in the distribution of genetic diversity are impacted by climate change. More population genetic studies of widespread Amazonian plant species would be useful to understand the demographic impacts of Pleistocene climatic changes in the Amazon drainage basin. However, there is a problem of proving causality of refugial population contractions based on levels of genetic diversity, since population expansions and contractions may result from disease outbreaks or other factors, including human-mediated dispersal. Furthermore, it is problematic to attribute speciation to specific Pleistocene events such as an individual glacial cycle, given the difficulties of performing molecular clock analyses at such recent timescales. However, recent studies provide evidence of plant diversification within a broad Pleistocene time frame in several groups including Inga, Guatteria, Renealmia and Costus (Richardson et al. 2001; Kay et al. 2005; Lavin 2006; Erkens et al. 2007). This is significant if only because early, influential reviews of tropical diversification (e.g. Moritz et al. 2000) emphasized pre-Pleistocene divergences in animals, which have subsequently been cited (e.g. Colinvaux et al. 2001) to refute the hypothesis of allopatric speciation resulting from forest fragmentation in the ice-age Amazon drainage basin.

\section{Ecological speciation: lowland habitats within the Amazon drainage basin}

The Amazonian rainforest contacts other biomes, especially montane forest along the Andes and savanna along its southern edge, and also some areas of seasonally dry tropical forest such as the Bolivian Chiquitano. Whilst many rainforest clades are confined to rainforest vegetation, others have species found in both rainforest and other neighbouring biomes. For example, many genera characteristic of rainforest are also found in seasonally dry tropical forest (Pennington et al. 2000), and of the 121 woody species that are dominant in the Brazilian cerrados, 99 come from genera also found in rainforest (Pennington et al. 2006b). Within the Amazonian rainforest, there is also habitat diversity resulting from changes in total precipitation and seasonality, temperature and soil type. Many authors have documented turnover in species composition across habitats in Amazonia and other rainforests (e.g. Tuomisto et al. 2003), and conclude that habitat diversity contributes to high species richness. However, such ecological studies do not demonstrate that habitat specialization (evolution between habitats), or at a broader scale 'biome specialization' (evolution between biomes), have actually driven diversification. Fortunately, phylogenetic approaches can address these issues.

Fine and co-workers $(2004,2005)$ examined the role of edaphic heterogeneity in the evolution of Burseraceae tree species in western Amazonia. Fine et al. (2005) demonstrated that of 35 species of Crepidospermum, Protium and Tetragastris of tribe Protieae, 26 were significantly associated with only one soil type and none was a generalist on all three of the white-sand, terrace and clay soils evaluated. Phylogenetic analysis of these species demonstrated multiple instances of convergent evolution of soil associations - put simply, species sharing the same soil preference were often unrelated. This convergent evolution implies that adaptive evolution may have played a considerable role in driving speciation, with an additional probable role of herbivory, because clay soil species suffer greater herbivore attack when growing on white-sand soils (Fine et al. 2004). However, the maximum amount of ecological speciation - an independent event underlying the origin of each species in each soil type - was not observed because in some cases putative sister taxa shared the same soil preference, implying that other processes must also be involved in diversification. Fine et al. (2005) sampled about half of the Amazonian species in Protieae, and a complete picture can be gained with more species sampling, which is almost certain to reveal more habitat switches across the entire tribe, but may also reveal clades of related species occupying the same soil type. Given the widespread nature of edaphic specialization in Amazonian tree species, similar studies in other taxa would be fruitful, with possible candidates being Inga, Swartzia (Leguminosae; Torke \& Schaal 2008) and Caryocar (Caryocaraceae; G. Prance, personal communication).

Fine et al. (2005) also attempted to correlate the sequence of edaphic specialization in Protieae with what is known of the 
historical development of soils in the Amazon drainage basin. In the Early Miocene, before the Late Miocene-Pliocene Andean uplift created the current Amazon River drainage, the western proto-Amazon drainage basin received sediments from the east, mostly from the granitic Brazilian and Guiana Shields (Fine et al. 2005). These produced an infertile, white-sand soil that today covers $3 \%$ of the Amazon drainage basin.

The more fertile terrace and clay soils result from weathering and deposition of Andean-derived sediments. Terrace soils are derived from sands and gravels deposited by Pliocene and Pleistocene rivers. Clay soils in western Amazonia originated from the erosion of Cretaceous metamorphic rocks from the Andes that were deposited in swamps, shallow lakes and in the vast lakes formed by marine incursions (Hoorn 1993).

This sequence of soil development predicts that white-sand specialization might be an ancestral (early branching) trait, which is observed in Potalia (Gentianaceae; Frasier et al. 2008), wherein species representing the basally divergent lineages of the genus are found on white-sand areas on the westernmost part of the Guiana Shield, and species representing the most recently derived lineages specialized on younger, more fertile sediments in other areas including the western Amazon drainage basin. However, in Protieae, there is a general trend of evolution from terrace soils to clay soils and white-sand soils. Fine et al. (2005) explain this by the possible extinction of older white-sand specialist lineages as this habitat decreased drastically in size.

The edaphic specialization of many species in the tree flora suggests that speciation across habitat boundaries has been an important driver of diversification within the Amazon rainforest biome. It is beyond the scope of this review to discuss the potential mechanism for such speciation except to note that the possibility of parapatric speciation - where divergent selection on individuals that promotes adaptation to different adjacent environments outweighs the effect of gene flow between them is regarded as increasingly feasible (Endler 1977; 1982; Levin 2004). What is less clear is how important broader scale 'habitat switching' - ecological speciation between different biomes - has been in the development of the Amazonian flora. An example is furnished by Ruprechtia (Polygonaceae), a genus of 37 species mostly confined to seasonally dry tropical forests but with 12 species also found in or confined to more moist forests, especially gallery forests (Pendry 2004). A phylogeny of Ruprechtia (Pennington et al. 2004b) sampled five of these rainforest species, and showed them to be placed in two recent (c. $1 \mathrm{Ma}$ ) clades that arise from dry-forest lineages. Ecological speciation between biomes is also discussed above in relation to montane lineages giving rise to Amazonian species, and the empirical example of Ruprechtia evolving from dry forest to rainforest does demonstrate the possibility of Amazonian diversity having been historically increased by speciation from other biomes. However, it is our impression that such biome switches may be rare, as confirmed in southern temperate and subtropical biomes (Crisp et al. 2009)

The concept of 'phylogenetic niche conservatism' (Harvey \& Pagel 1991; Ricklefs \& Latham 1992; Wiens 2004) - that lineages tend to maintain their ancestral ecological predilection has much empirical support, and underlies many comparative methods in evolutionary biology (e.g. Harvey \& Pagel 1991), so perhaps it should not be surprising that biome switches in evolution should be rare. After all, survival in different biomes presumably requires a whole suite of adaptations. For the Leguminosae, which dominate the Amazonian flora, diversification does seem to have been constrained by ecology (Schrire et al. 2005; Lavin \& Beyra 2008). Species in legume clades tend to occupy the same broadly defined biomes (Schrire et al. 2005), implying that biome switches have been infrequent. Ecology can be a better predictor of legume relationships than geography. For example, temperate legume lineages show disjunctions between the northern and southern hemispheres, but there are no instances of temperate legumes giving rise to tropical clades. The same may be true for Ruellia (Acanthaceae; Tripp 2007), where in a principally rainforest genus, small clades ecologically confined to dry forest, savanna and subtropical biomes contain species that are collectively widespread throughout the Neotropics.

Whether such phylogenetic niche conservatism is true for other major plant clades is hard to discern because phylogenetic systematists have failed to pay the same attention to ecology and geography as they have to morphology. There are indications that biome preference may be more labile in other groups, for example in Bignoniaceae (Grose \& Olmstead 2007). It is clear that more phylogenetic studies of clades that contain species growing in multiple biomes are necessary to examine the frequency and direction of biome switching in Neotropical plant evolution. Some such studies are underway, for example of Mimosa (Leguminosae), whose 400 species are found both in rainforest, seasonally dry tropical forest and savannas (Simon \& Hughes 2007). Groups that would be useful to study in this context for the Amazonian flora would be Lauraceae (also species-rich in montane forest), Qualea (Vochysiaceae; three species are amongst the ecological dominants of the Brazilian cerrados) and Zanthoxylum (Rutaceae; species grow in rainforest, temperate deciduous forest, dry forest and savanna).

\section{Conclusions and outlook}

We suggest that the effects on the diversification patterns of lowland Amazonian plants of putative Neogene drivers of diversification (riverine barriers, tectonic arches, marine incursions) may be hard to discern because of the subsequent homogenizing effects of gene flow caused by long-distance seed dispersal in many plants. This view, which emphasizes long-distance dispersal, is partly based upon its increasingly clear influence at broader geographical scales (e.g. transoceanic dispersals) and at deeper timescales. Furthermore, at these deeper and broader scales, there are preliminary indications (reviewed by Pennington et al. 2006b) that in temperate and subtropical areas, dates for the same geographical divergences are older for animals than for plants, implying a greater propensity for plants to disperse and establish. Our suggestion is that in many Amazonian plant lineages, over timescales of millions of years, dispersal will overwrite and obscure any genetic signature of a specific event that may have existed.

This concept of historical 'dispersal overwrite' in the Amazonian lowland flora is supported by the lack of geographical structure in Amazonian plant phylogenies. The lack of phylogenetic geographical structure - meaning that species growing in the same geographical area are not each others' closest relatives - is illustrated for the genus Renealmia in Fig. 23.2, where the highlighted 


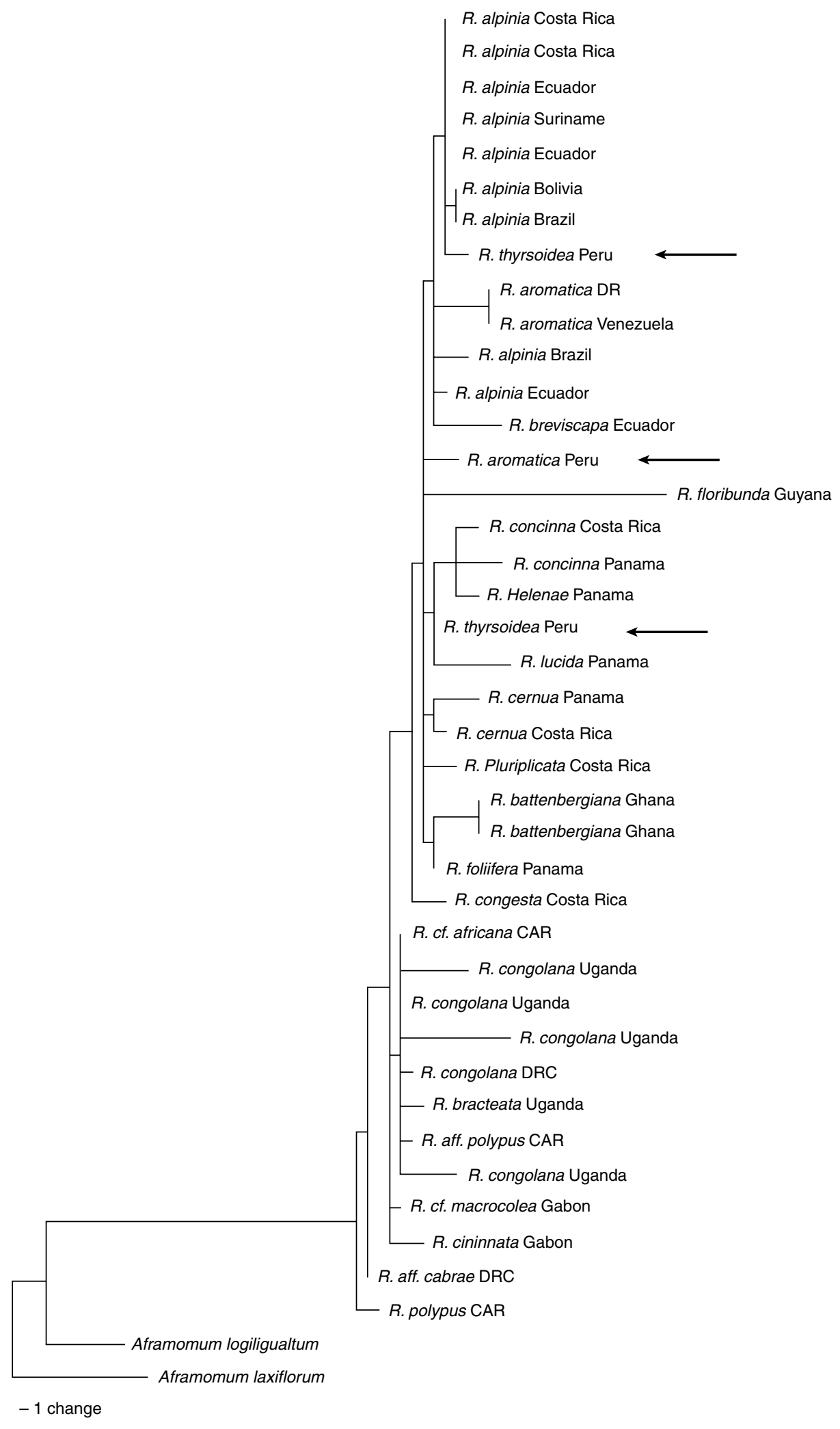

Fig. 23.2 Lack of phylogenetic geographical structure in Renealmia (Zingiberaceae); Bayesian phylogenetic tree from Särkinen et al. (2007) with branch lengths proportional to the number of substitutions. Arrows highlight species from Peru. DR, Dominican Republic; DRC, Democratic Republic of Congo; CAR, Central African Republic. Modified from Sarkinen et al. (2007). 
accessions of species from Peru are scattered across the tree rather than in a single clade. Similarly, low geographical structure has been documented in Inga (Lavin 2006), Clusia (Gustaffson \& Bittrich 2003), Ruellia (Tripp 2007) and Guatteria (Erkens et al. 2006). Lack of phylogenetic geographical structure has a clear implication for community assembly - that in a given area of Amazonian rainforest, species in these genera are unlikely to be each others' closest relatives.

Testing the generality of patterns of phylogenetic geographical structure will require study of more groups. However, we predict that because most Amazonian trees are broadly dispersed by vertebrates, wind and water, their phylogenetic geographical structure will be low. Dispersal is only half of the equation, and characteristics that enable successful establishment, such as ability to self-fertilize, vegetative reproduction and pioneer habit, may also influence biogeographical patterns. It follows that if one is seeking plant study groups that will retain the signature of Neogene events such as marine incursions and tectonic arches, these should lack such attributes and have low pollen and seed dispersal distances, perhaps being pollinated by small insects or wind, and dispersed by gravity or terrestrial mammals. A possible example is the herbaceous rainforest genus Pilea, where winddispersed pollen and mechanically dispersed fruits may generally travel only a few millimetres (Monro 2007), and whose phylogeny is highly congruent with geography (Monro 2006).

Although this book is focused on Neogene drivers of plant diversification in Amazonia, we have devoted at least an equal amount of attention to processes that extend deeper in time, and which include other continents. This perspective of deeper timescale and broader geographical scale helps reveal the importance of long-distance dispersal as a biogeographical process and helps to place Neogene history into context. However, this emphasis also reflects constraints of the current molecular toolbox to address more recent events. With the development of multi-locus genetic markers such as single nucleotide polymorphisms (SNPs) and microsatellites for large numbers of Amazonian species, and statistical procedures to test hypotheses on recent timescales (Knowles 2003), we can hope to address a range of interesting later Neogene Amazon vicariance hypotheses about plants.

\section{Acknowledgements}

We thank Alejandra Jaramillo, Lena Struwe, Erin Tripp, Alex Monro, Bill Baker and C. Borne for access to unpublished manuscripts and information, and Paul Fine, Carina Hoorn and Ghillean Prance for their thoughtful reviews.

\section{References}

Aide, T.M., Rivera, E. (1998) Geographic patterns of genetic diversity in Poulsenia armata (Moraceae): implications for the theory of Pleistocene refugia and the importance of riparian forest. J Biogeogr 25, 695-705.

Antonelli, A., Nylander, J.A.A., Persson, C., Sanmartín, I. (2009) Tracing the impact of the Andean uplift on neotropical plant evolution. Proc Natl Acad Sci USA doi:10.1073/pnas.0811421106.
Baker, W.J., Dransfield, J. (2000) Towards a biogeographic explanation of the calamoid palms. In: Wilson, K.L., Morrison, D.A. (eds) Monocots: Systematics and Evolution. Melbourne: CSIRO, pp. 545-553.

Berry, P.E., Hahn, W.J., Sytsma, K.J., Hall, J.C., Mast, A. (2004) Phylogenetic relationships and biogeography of Fuchsia (Onagraceae) based on noncoding nuclear and chloroplast DNA data. Am J Bot 91, 601-614.

Born, C. (2007) Diversité génétique et dynamique des forêts d'Afrique centrale. Une étude multi-échelle de la structure de la diversité génétique d'un arbre pionnier, Aucoumea klaineana. $\mathrm{PhD}$ dissertation, Université de Montpellier II, Montpellier, France.

Brumfield, R.T., Edwards, S.V. (2007) Evolution into and out of the Andes: a Bayesian analysis of historical diversification in Thamnophilus antshrikes. Evolution 61, 346-367.

Coates, A.G., Obando, J.A. (1996) The geologic evolution of the Central American Isthmus. In: Jackson, J.B.C., Budd, A.F., Coates, A.G. (eds) Evolution and Environment in Tropical America. Chicago: University of Chicago Press, pp. 21-56.

Chanderbali A.S., Van der Werff, H., Renner, S.S. (2001) Phylogeny and historical biogeography of Lauraceae: evidence from the chloroplast and nuclear genomes. Ann MO Bot Gard 88, 104-134.

Colinvaux, P., Irion, G., Räsänen, M.E., Bush, M.B. (2001) A paradigm to be discarded: Geological and paleoecological data falsify the Haffer \& Prance refuge hypothesis of Amazonian speciation. Amazoniana 16, 609-646.

Crisp, M.D., Arroyo, M.T.K., Cook, L.G., Gandolfo, M.A., Jordon, G.J., McGlone, M.S., Weston, P.H., Westoby, M., Wilf, P., Linder, H.P. (2009) Phylogenetic biome conservatism on a global scale. Nature 458, 754-756.

Davis, C.C., Bell, C.D., Mathews, S., Donoghue, M. (2002) Laurasian migration explains Gondwanan disjunctions: evidence from Malpighiaceae. Proc Natl Acad Sci USA 99, 6833-6837.

Dick, C.W., Abdul-Salim, K., Bermingham, E. (2003) Molecular systematics reveals cryptic Tertiary diversification of a widespread tropical rainforest tree. Am Nat 162, 691-703.

Dick, C.W., Condit, R., Bermingham, E. (2005) Biogeographic history and the high $\beta$-diversity of rainforest trees in Panamá. In: Harmon, R. (ed.) Rio Chagres: A Multi-disciplinary Profile of a Tropical Watershed. New York: Springer Publishing Company, pp. 259-268.

Dick, C.W., Bermingham, E., Lemes, M.R., Gribel, R. (2007) Extreme long-distance dispersal of the lowland tropical rainforest tree Ceiba pentandra L. (Malvaceae) in Africa and the Neotropics. Mol Ecol 16, 3039-3049.

Dick, C.W., Hardy, O.J., Jones, F.A., Petit, R.J. (2008) Spatial scales of pollen and seed-mediated gene flow in lowland tropical rain forest trees. Trop Plant Biol 1, 20-33.

Dransfield, J., Uhl, N.W., Asmussen-Lange, C.B., Baker, W.J., Harley, M.M., Lewis, C.E. (2008) Genera Palmarum - Evolution and Classification of the Palms. Kew: Royal Botanic Gardens.

Dutech, C., Maggia, L., Tardy, C., Joly, H.I., Jarne, P. (2003) Tracking a genetic signal of extinction-recolonization events in a Neotropical tree species: Vouacapoua americana Aublet in French Guiana. Evolution 57, 2753-2764.

Endler, J.A. (1977) Geographic Variation, Speciation and Clines. Princeton: Princeton University Press.

Endler, J.A. (1982) Pleistocene forest refuges: fact or fancy. In: Prance, G.T. (ed.) Biological Diversification in the Tropics. New York: Columbia University Press, pp. 641-657.

Erkens, R.H.J., Chatrou, L.W., Maas, J.W., van der Niet, T., Savolainen, V. (2007) A rapid diversification of rainforest trees (Guatteria; Annonaceae) following dispersal from Central into South America. Mol Phylogenet Evol 44, 399-411. 
Fine, P.V.A., Mesones, I., Coley, P.D. (2004) Herbivores promote habitat specialization by trees in Amazonian forests. Science 305, 663-665.

Fine, P.V.A., Daly, D.C, Villa Muñoz, G., Mesones, I., Cameron, K.M. (2005) The contribution of edaphic heterogeneity to the evolution and diversity of Burseraceae trees in the western Amazon. Evolution $59,1464-1478$

Fjeldså, J. (1994) Geographical patterns for relict and young species of birds in Africa and South America and implications for conservation priorities. Biodivers Conserv 3, 207-226.

Fjeldså, J., Lovett, J.C. (1997) Geographical patterns of old and young species in African forest biota: the significance of montane areas as evolutionary centres. Biodivers Conserv 6, 325-346.

Frasier, C.L., Albert, V.A., Struwe, L. (2008) Amazonian lowland, white sand areas as ancestral regions for South American biodiversity: biogeographic and phylogenetic patterns in Potalia (Angiospermae: Gentianaceae). Org Divers Evol 8, 144-57.

Gaut, B.S. (1998) Molecular clocks and nucleotide substitution rates in higher plants. Evol Biol 30, 93-120.

Gentry, A. (1982) Neotropical floristic diversity: phytogeographical connections between Central and South America. Pleistocene climatic fluctuations or an accident of Andean orogeny? Ann MO Bot Gard 69, 557-593.

Gentry, A.H. (1993) Diversity and floristic composition of lowland tropical forest in Africa and South America. In: Goldblatt, P. (ed.) Biological Relationships Between Africa and South America. New Haven: Yale University Press, pp. 500-547.

Graham, A., Gregory-Wodzicki, K.M., Wright, K.L. (2001) Studies in neotropical paleobotany. XV. A Mio-Pliocene palynoflora from the Eastern Cordillera, Bolivia: implications for the uplift history of the Central Andes. Am J Bot 88, 1545-1557.

Granville, J.-J. de (1982) Rain forest and xeric refuges in French Guiana. In: Prance, G.T. (ed.) Biological Diversification in the Tropics. New York: Columbia University Press, pp. 137-158.

Graur, D., Martin, W. (2004) Reading the entrails of chickens: molecular timescales of evolution and the illusion of precision. Trends Genet 20, 80-86.

Gregory-Wodzicki, K.M. (2000) Uplift history of the Central and Northern Andes: a review. GSA Bulletin 112, 1091-1105.

Grose, S.O., Olmstead, R.G. (2007) Evolution of a charismatic neotropical clade: molecular phylogeny of Tabebuia s.l. (Bignoniaceae). Syst Bot 32, 650-659.

Gustafsson, M., Bittrich, V. (2003) Evolution of morphological diversity and resin secretion in flowers of Clusia L. (Clusiaceae) insights from ITS sequence variation. Nordic J Bot 22, 183-203.

Harvey, P.H., Pagel, M.D. (1991) The Comparative Method in Evolutionary Biology. Oxford: Oxford University Press.

Heads, M. (2005) Dating nodes on molecular phylogenies: a critique of molecular biogeography. Cladistics 21, 62-78.

Hewitt, G.M. (1996) Some genetic consequences of ice ages, and their role in divergence and speciation. Biol J Linn Soc 58, 247-276.

Hickerson, M.J., Dolman, G., Moritz, C. (2006) Comparative phylogeographic summary statistics for testing simultaneous vicariance. Mol Ecol 15, 209-223.

Hoorn, C. (1993) Marine incursions and the influence of Andean tectonics on the Miocene depositional history of northwestern Amazonia: results of a palynostratigraphic study. Palaeogeogr Palaeocl 105, 267-309.

Hughes, C., Eastwood, R. (2006) Island radiation on a continental scale: Exceptional rates of plant diversification after uplift of the Andes. Proc Natl Acad Sci USA 103, 10334-10339.

Iturraldi-Vinent, M.A., MacPhee, R.D.E. (1999) Paleogeography of the Caribbean region: Implications for Cenozoic biogeography. Bull Am Mus Nat Hist 236, 1-95.
Jaramillo, C., Rueda, M.J., Mora, G. (2006) Cenozoic plant diversity in the Neotropics. Science 311, 1893-1896.

Jaramillo, M.A., Calleja, R., Davidson, C., Smith, J.F., Stevens, A.C., Tepe, E.J. (2008). A phylogeny of the tropical genus Piper using ITS and the chloroplast intron psbJ-petA. Syst Bot 33, 647-660.

Jørgensen, P.M., León, S. (eds) (1999) Catalogue of the vascular plants of Ecuador. Monog Syst Botan 75, i-vii, 1-1181.

Kay, K.M., Reeves, P., Olmstead, R., Schemske, D.W. (2005) Rapid speciation and the evolution of hummingbird pollination in neotropical Costus subgenus Costus (Costaceae): evidence from nrDNA ITS and ETS sequences. Am J Bot 92, 1899-1910.

Kay, K.M., Whitall, J.B., Hodges, S.A. (2006) A survey of nuclear ribosomal internal transcribed spacer substitution rates across angiosperms: an approximate molecular clock with life history effects. BMC Evol Biol 6, 36. doi:10.1186/1471-2148-6-36.

Kenicer, G., Kajita, T., Pennington, R.T., Murata, J. (2005) Systematics and biogeography of Lathyrus based upon internal transcribed spacer and cpDNA sequence data. Am J Bot 92, 1199-1209.

Knowles, L.L. (2003) The burgeoning field of statistical phylogeography. J Evol Biol 17, 1-10.

Koch, M., Al-Shehbaz, I.A. (2002) Molecular data indicate complex intra- and intercontinental differentiation of American Draba. Ann MO Bot Gard 89, 88-109.

Lavin, M. (2006) Floristic and geographical stability of discontinuous seasonally dry tropical forests explains patterns of plant phylogeny and endemism. In: Pennington R.T., Lewis, G.P., Ratter, J.A. (eds) Neotropical Savannas and Seasonally Dry Forests: Plant Diversity, Biogeography and Conservation. CRC Press, pp. 433-448.

Lavin, M., Beyra, A. (2008) The impact of ecology and biogeography on legume diversity, endemism and phylogeny in the Caribbean region. Bot Rev 74, 178-196.

Lavin, M., Schrire, B., Lewis, G., Pennington, R.T., DelgadoSalinas, A., Thulin, M. et al. (2004) Metacommunity process rather than continental tectonic history better explains geographically structured phylogenies in legumes. Philos $T R$ Soc B 359, 1509-1522.

Lavin, M., Herendeen, P.S., Wojciechowski, M.F. (2005) Evolutionary rates analysis of Leguminosae implicates a rapid diversification of lineages during the Tertiary. Syst Biol 54, 575-594.

Levin, D.A. (2004) Ecological speciation: crossing the divide. Syst Bot $29,807-816$.

Li, W.-H. (1997) Molecular Evolution, 1st edn. Sunderland MA: Sinauer.

McLachlan, J.S., Clark, J.S., Manos, P.S. (2005) Molecular indicators of tree migration capacity under rapid climate change. Ecology 86, 2088-2098.

Monro, A.K. (2006) The revision of species-rich genera: a phylogenetic framework for the strategic revision of Pilea (Urticaceae) based upon cpDNA, nrDNA and morphology. Am J Bot 93, 426-441.

Monro, A.K. (2007) Taxonomy of Pilea (Urticaceae). Critical Appraisal. Submitted as part of a PhD by published work. Oxford: Oxford Brookes University.

Moritz,C.,Patton,J.L.,Schneider,C.J.,Smith T.B. (2000) Diversification of rain forest faunas: an integrated molecular approach. Ann Rev Ecol Syst 31, 553-563.

Morley, R.J. (2000) Origin and Evolution of Tropical Rain Forests. Chichester: John Wiley \& Sons Ltd.

Morley, R.J. (2003) Interplate dispersal paths for megathermal angiosperms. Perspect Plant Ecol 6, 5-20.

Muellner, A.N., Savolainen, V., Samuel, R., Chase, M.W. (2006) The mahogany family "out-of-Africa": Divergence time estimation, global biogeographic patterns inferred from plastid rbcL DNA 
sequences, extant, and fossil distribution of diversity. Mol Phylogenet Evol 40, 236-250.

Near T.J., Sanderson, M.J. (2004) Assessing the quality of molecular divergence time estimates by fossil calibrations and fossil-based model selection. Philos T R Soc B 359, 1477-1483.

Nettel, A., Dodd, R.S. (2007) Drifting propagules and receding swamps: Genetic footprints of mangrove recolonization and dispersal along tropical coasts. Evolution 61, 958-971.

Pendry, C.A. (2004) A Monograph of Ruprecthia (Polygonaceae). Systematic Botany Monographs 67, pp. 12-17.

Pennington, R.T., Dick, C.W. (2004) The role of immigrants in the assembly of the South American rainforest tree flora. Philos T R Soc B 359, 1611-1622.

Pennington, R.T., Prado, D.A., Pendry, C. (2000) Neotropical seasonally dry forests and Pleistocene vegetation changes. J Biogeogr 27, 261-273.

Pennington, R.T., Hollingsworth, M., Ponge, A., Zamora, N. (2003) Tropical mountains and plant evolution: the influence of the Andes on Dussia. In: Association for Tropical Biology and Conservation, Annual Meeting, Abstracts for talks, 38.

Pennington, R.T., Lavin, M., Prado, D.E., Pendry, C.A., Pell, S., Butterworth, C.A. (2004a) Historical climate change and speciation: Neotropical seasonally dry forest plants show patterns of both Tertiary and Quaternary diversification. Philos T R Soc B 359, 515-538.

Pennington, R.T., Pendry, C.A., Goodall-Copestake, W., O’Sullivan, S. (2004b) Phylogenetic analysis of Ruprechtia. In: Pendry, C.A. (ed.) A Monograph of Ruprecthia (Polygonaceae). Systematic Botany Monographs 67, pp. 12-17.

Pennington, R.T., Ratter, J.A., Lewis, G.P. (2006a) An overview of the plant diversity, biogeography and conservation of neotropical savannas and seasonally dry forests. In: Pennington, R.T., Lewis, G.P., Ratter., J.A. (eds) Neotropical Savannas and Seasonally Dry Forests: Plant Diversity, Biogeography and Conservation. CRC Press, pp. 1-29.

Pennington, R.T., Richardson, J.A. Lavin, M. (2006b) Insights into the historical construction of species-rich biomes from dated plant phylogenies, phylogenetic community structure and neutral ecological theory. New Phytol 172, 605-616.

Pennington, T.D. (1997) The Genus Inga. Kew: Royal Botanic Gardens.

Petit, R.J., Pineau, E., Demesure, B., Bacilieri, R., Ducousso, A., Kremer, A. (1997) Chloroplast DNA footprints of postglacial recolonization by oaks. Proc Natl Acad Sci USA 94, 996-1001.

Petit, R.J., Aguinagalde, I., de Beaulieu, J.L., Bittkau, C., Brewer, S., Cheddadi, R. et al. (2003) Glacial refugia: hotspots but not melting pots of genetic diversity. Science 300, 1563-1565.

Petit, R.J., Hu, F.S., Dick, C.W. (2008) Forests of the past: a window to future changes. Science 320, 1450-1452.

Pirie, M.D., Chatrou, L.W., Mols, J.B., Erkens, R.H.J., Oosterhof, J. (2006) 'Andean-centred' genera in the short-branch clade of Annonaceae: Testing biogeographic hypotheses using phylogeny reconstruction and molecular dating. J Biogeogr 33, 31-46.

Pitman, W.C.I., Cande, S., LaBreque, J., Pindell, J. (1993) Fragmentation of Gondwana: the separation of Africa from South America. In: Goldblatt, P. (ed.) Biological Relationships between Africa and South America. New Haven: Yale University Press, pp. 202-213.

Plana V., Gascoigne, A., Forest, L.L., Harris, D., Pennington, R.T. (2004) Pleistocene and pre-Pleistocene speciation in Africa. Mol Phylogenet Evol 31, 449-461.

Raven, P.H. (1999) Foreword. Monog Syst Botan 75, vii-viii.
Raven, P.H., Axelrod, D.I. (1974) Angiosperm biogeography and past continental movements. Ann MO Bot Gard 61, 539-673.

Renner, S.S. (2005) Relaxed molecular clocks for dating historical plant dispersal events. Trends Ecol Evol 10, 550-556.

Renner S.S., Clausing, G., Meyer, K. (2001) Historical biogeography of Melastomataceae: the roles of Tertiary migration and longdistance dispersal. Am J Bot 88, 1290-1300.

Richardson, J.E., Pennington, R.T., Pennington, T.D., Hollingsworth, P.M. (2001) Rapid diversification of a species-rich genus of neotropical rain forest trees. Science 293, 2242-2245.

Richardson, J.E., Chatrou, L.W., Mols, J.B., Erkens, R.H.J., Pirie, M.D. (2004) Historical biogeography of two cosmopolitan families of flowering plants. Philos T R Soc B 359, 1495-1508.

Ricklefs, R.E., Latham, R.E. (1992) Intercontinental correlation of geographical ranges suggests stasis in ecological traits of relict genera of temperate perennial herbs. Am Nat 139, 1305-1321.

Rutschman, F. (2006) Molecular dating of phylogenetic trees: A brief review of current methods that estimate divergence times. Divers Distrib 12, 35-48.

Sánchez-Baracaldo, X. (2004) Phylogenetics and biogeography of the neotropical fern genera Jamesonia and Eriosorus (Pteridaceae). Am J Bot 91, 274-284.

Särkinen, T.E., Newman, M.F., Maas, P.J.M., Maas, H. Poulsen, A.D., Harris, D.J. et al. (2007) Recent oceanic long-distance dispersal and divergence in the amphi-Atlantic rain forest genus Renealmia L.f. (Zingiberaceae). Mol Phylogenet Evol 44, 968-980.

Schrire B.D., Lavin, M., Lewis, G.P. (2005) Global distribution patterns of the Leguminosae: insights from recent phylogenies. Biologiske Skrifter 55, 375-422.

Simon, M.F., Hughes, C.E. (2007) Phylogeny of Mimosa (Leguminosae) supports a recent origin for the Cerrado biome in Brazil. In: Sixth Biennial Conference of The Systematics Association, Edinburgh, UK. Abstract Book, p. 20.

Simpson, G.G. (1980) Splendid Isolation: the Curious History of South American Mammals. New Haven: Yale University Press

Smedmark, J.E.E., Anderberg, A.A. (2007) Boreotropical migration explains hybridisation between geographically distinct lineages in the pantropical clade Sideroxyleae (Sapotaceae). Am J Bot 94, 1491-1505.

Stebbins, G.L. (1974) Flowering Plants: Evolution Above the Species Level. Cambridge, MA: Harvard University Press.

Stehli, F.G., Webb, D.S. (1985) A kaleidoscope of plates, faunal and floral dispersals, and sea level changes. In: Stehli, F.G., Webb, D.S. (eds) The Great American Biotic Interchange. New York: Plenum Press, pp. 3-16.

Thorne, R.F. (1973) Floristic relations between tropical Africa and tropical America. In: Meggers, B., Ayesu E., Duckworth, W. (eds) Tropical Forest Ecosystems in Africa and South America: A Comparative Review. Washington DC: Smithsonian Institution Press, pp. 27-47.

Tiffney, B.H. (1985) The Eocene North Atlantic land bridge: its importance in Tertiary and modern phytogeography of the northern hemisphere. J Arnold Arboretum 66, 73-94.

Torke, B.M., Schaal, B.A. (2008) Molecular phylogenetics of the species-rich neotropical genus Swartzia (Leguminosae, Papilionoideae) and related genera of the swartzioid clade. Am J Bot 95, 215-228.

Trénel, P., Gustafsson, M., Baker, W.J., Asmussen-Lange, C.B., Dransfield, J., Borchsenius, F. (2007) Mid-Tertiary dispersal, not Gondwanan vicariance explains distribution patterns in the wax palm subfamily (Ceroxyloideae: Arecaceae). Mol Phylogenet Evol 45, 272-288. 
Tripp, E. (2007) Evolutionary relationships within the species-rich genus Ruellia. Syst Bot 32, 628-649.

Tuomisto, H., Ruokolainen, K., Yli-Halla, M. (2003) Dispersal, environment and floristic variation of Western Amazonian forests. Science 299, 241-244.

Valencia, R., Foster, R.B., Villa, G., Condit, R., Svenning, J.C., Hernández, C. et al. (2004) Tree species distributions and local habitat variation in the Amazon: large forest plot in eastern Ecuador. J Ecol 92, 214-229.

Van der Hammen, T., Werner, J.H., van Dommelen, H. (1973) Palynological record of the upheaval of the Northern Andes: a study of the Pliocene and lower Quaternary of the Colombian Eastern Cordillera and the early evolution of its High-Andean biota. Rev Palaeobot Palynol 16, 1-122.

Wallace, A.R. (1878) Tropical Nature and Other Essays. New York: Macmillan.

Weeks, A., Daly, D.C., Simpson, B.B. (2005) The phylogenetic history and biogeography of the frankincense and myrrh family
(Burseraceae) based upon nuclear and chloroplast sequence. Mol Phylogenet Evol 35, 85-101.

Whitmore, T.C. (1998) An Introduction to Tropical Rain Forests, 2nd edn. Oxford: Oxford University Press.

Wiens, J.J. (2004) Speciation and ecology revisited: phylogenetic niche conservatism and the origin of species. Evolution 58, 193-197.

Wolfe, K.H., Li, W.-H., Sharp, P.M. (1987) Rates of nucleotide substitution vary greatly among plant mitochondrial, chloroplast, and nuclear DNAs. Proc Natl Acad Sci USA 84, 9054-9058.

Young, K.R., Ulloa, C.U., Luteyn, J.L., Knapp, S. (2002) Plant evolution and endemism in Andean South America: an introduction. Bot Rev $68,4-21$.

Zerega N.J.C., Clement, W.L., Datwyler, S.L., Weiblen, G.D. (2005). Biogeography and divergence times in the mulberry family (Moraceae). Mol Phylogenet Evol 37, 402-416. 